Jurnal At-Tibyan: Jurnal Ilmu Alqur'an dan Tafsir

Volume 5 No. 1, Juni 2020 (h.90-103)

P ISSN 2442-594X | E ISSN 2579-5708

http://journal.iainlangsa.ac.id/index.php/tibyan

\title{
GERAKAN MEMBUMIKAN TAFSIR AL-QUR'AN DI INDONESIA: Studi M. Quraish Shihab atas Tafsir Al-Misbah
}

\section{Movements Turning The Qur'anic's Tafsir In Indonesia: M. Quraish Shihab's study of Al-Misbah's Interpretation}

\begin{tabular}{|c|c|c|}
\hline \multicolumn{3}{|c|}{$\begin{array}{c}\text { Muhammad Alwi HS } \\
\text { UIN Sunan Kalijaga Yogyakarta } \\
\text { muhalwihs2@gmail.com }\end{array}$} \\
\hline \multicolumn{3}{|c|}{$\begin{array}{c}\text { Muhammad Arsyad } \\
\text { UIN Sunan Kalijaga Yogyakarta } \\
\text { arsyadmhd93@gmail.com }\end{array}$} \\
\hline $\begin{array}{r}\text { UIN S } \\
\text { muhammac }\end{array}$ & $\begin{array}{l}\text { Muhammad Akm } \\
\text { unan Kalijaga Yo } \\
\text { akmalhikmawanl }\end{array}$ & $\begin{array}{l}1 \\
\text { yakarta } \\
\text { agmail.com }\end{array}$ \\
\hline \multicolumn{3}{|c|}{ DOI: $10.32505 /$ tibyan. v5i1.1320 } \\
\hline Submitted: 23-11-2019 & Revised: $19-06-2020$ & Accepted: $28-06-2020$ \\
\hline
\end{tabular}

\begin{abstract}
This article discusses the phenomenon of grounding the interpretation of the Qur'an in Indonesia by focusing on M. Quraish Shihab as a moderncontemporary interpreter who successfully interprets the Qur'an in written and oral form. The important location of M. Quraish Shihab in grounding the interpretation of the Qur'an lies in his efforts to interpret the Qur'an with language that is easy to understand but has high quality content. This makes M. Quraish Shihab always an important reference in the interpretation of the Qur'an in Indonesia, both among Al-Qur'an scholars and ordinary people. Tafsir Al-Misbah is evidence of success in grounding the interpretation of the Qur'an in Indonesia, both in the form of commentaries and studies. Kitab Tafsir Al-Misbah is the work of Phenomenal M. Quraish Shihab in simplifying the language of its interpretation, having previously been considered to be rambling on Kitab Tafsir Al-Qur'an 'Al-Karim. Meanwhile, the "Kajian Tafsir Al-Misbah" was born as an effort to maintain the understanding of the Qur'an by experts, so that the public gets enlightened understanding of the Qur'an by people who are truly in their capacity as interpreters of the Qur'an.
\end{abstract}

Keywords: Tafsir Indonesia, M. Quraish Shihab, Book of Tafsir Al-Misbah, Study of Tafsir Al-Misbah. 


\begin{abstract}
Abstrak
Artikel ini membahas tentang fenomena membumikan tafsir al-Qur'an di Indonesia dengan berfokus kepada M. Quraish Shihab sebagai penafsir modern-kontemporer yang berhasil menafsirkan al-Qur'an dalam bentuk tulis dan lisan. Letak penting M. Quraish Shihab dalam membumikan tafsir alQur'an terdapat pada upayanya menafsirkan Al-Qur'an dengan bahasa yang mudah dipahami tetapi isi bahasannya yang berkualitas. Hal ini menjadikan M. Quraish Shihab senantiasa menjadi rujukan penting penafsiran al-Qur'an di Indonesia, baik di kalangan sarjana Al-Qur'an maupun masyarakat awam. Tafsir Al-Misbah adalah bukti keberhasilan dalam membumikan tafsir AlQur'an di Indonesia, baik dalam bentuk kitab tafsir maupun kajian. Kitab Tafsir Al-Misbah adalah karya Fenomenal M. Quraish Shihab dalam menyederhakan bahasa penyampaian penafsirannya, setelah sebelumnya dianggap bertele-tele pada kitab Tafsir al-Qur'an Al-Karimnya. Sementara, "Kajian Tafsir Al-Misbah" lahir sebagai upaya menjaga pemahaman AlQur'an oleh ahlinya, sehingga masyarakat mendapat penerangan pemahaman al-Qur'an oleh orang yang benar-benar berada dalam kapasitasnya sebagai penafsir al-Qur'an. Di samping itu, penyajian penafsiran al-Qur'an M. Quraish Shihab mengalami inovasi, perubahan dan perkembangan makna dari apa yang disampaikan dalam bentuk kitab Tafsir hingga disampaikan dalam bentuk lisan pada "Kajian Tafsir Al-Misbah" di MetroTV.
\end{abstract}

Kata Kunci: Tafsir Indonesia, M. Quraish Shihab, Kitab Tafsir Al-Misbah, Kajian Tafsir Al-Misbah

\title{
Pendahuluan
}

Semenjak al-Qur'an dituliskan dalam bentuk Mushaf, ia mengalami 'bebas konteks' atau wacana 'mandiri', sehingga terbuka untuk dipahami dan ditafsirkan kapanpun dan oleh siapapun. Muhammad Karim Al-Kawwaz mengatakan bahwa beralihnya al-Qur'an dari lisan ke tulisan (Mushaf) menjadikannya lebih dominan dibaca, dikaji hingga dipahami sebagai teks tulis. ${ }^{2}$ Dari sini, tafsir sebagai gerakan intelektual dan sebagai produk pemikiran ${ }^{3}$ senantiasa berperan penting dalam membumisasikan al-Qur'an. Hal ini dapat diketahui melalui kekayaan tersendiri yang dimiliki oleh kajian tafsir al-Qur'an sepanjang sejarah, dari masa Nabi Muhammad hingga saat ini. ${ }^{4}$ Al-Raghib Al-Ashfahani mengatakan bahwa menafsirkan adalah cara yang dilakukan manusia untuk menemukan maksud dan rahasia yang disampaikan

\footnotetext{
${ }^{1}$ Lihat lebih jauh Walter J. Ong, Kelisanan dan Keaksaraan, terj. Rika Iffati (Yogyakarta: Gading Publishing, 2013), 117-118.

${ }^{2}$ Muhammad Karim al-Kawwaz, Kalam Allah: al-Janib al-Syafahi min al-Zahirah Al-Qur'aniyyah (Bairut: Dar al-Saqi, 2002), 10.

${ }^{3}$ Lihat penjelasan lebih jauh dalam Abdul Mustaqim, Pergeseran Epistemologi Tafsir (Yogyakarta: PT LKiS Printing Cemerlang, 2011), 32.

${ }^{4}$ M. Alfatih Suryadilaga dkk, Metodologi Ilmu Tafsir (Yogyakarta: Penerbit Teras, 2010), 40.
} 
Allah SWT yang tercantum dalam Al-Qur'an. ${ }^{5}$ Usaha penemuan maksud dan rahasia Allah dalam Al-Qur'an ini merupakan usaha untuk membicarakan wahyu dengan konteks kehidupan yang mengalami perubahan dari zaman ke zaman, serta dari satu tempat ke tempat lainnya. ${ }^{6}$

Di Indonesia sendiri penafsiran Al-Qur'an terus mengalami perkembangan yang signifikan, hal ini mengikut perkembangan zaman. Penafsiran yang semula hanya berkisar dalam bentuk kitab tafsir atau buku-buku keagamaan lainnya, namun seiring perkembangan teknologi yang melahirkan berbagai media: Televisi, Youtube, Facebook atau media sosial lainnya, menambah maraknya penafsiran Al-Qur'an selain dalam bentuk kitab tafsir, seperti tafsir di media sosial, tafsir lisan, dan sebagainya. Berkenaan dengan ini, Muhammad Quraish Shihab merupakan salah satu penafsir AlQur'an kontemporer Indonesia yang sangat produktif dalam penyampaikan penafsirannya, baik dalam bentuk kitab tafsir maupun media sosial, di antaranya adalah kitab Tafsir Al-Misbah dan "Kajian Tafsir Al-Misbah" di MetroTV.

Selain itu, M. Quraish Shihab juga termasuk ulama dan intelektual yang mudah dipahami dalam menyampaikan penafsirannya. ${ }^{7}$ Lebih jauh, selain dengan bahasanya yang mudah dipahami untuk orang awam, kandungan penjelasannya dapat berskala terpelajar. ${ }^{8}$ Baik dalam kitab tafsir al-Mishbah-nya, maupun dalam penyampaian ceramahnya. Yang demikian itu sebagaimana disanjungkan oleh Pengantar Redaksi Kompas bahwa "Menyejukkan", ini kesan yang timbul saat membaca tulisannya tentang berbagai persoalan kemasyarakan dan keagamaan. Begitu pula bila mendengar ceramahnya." Dari sini, artikel ini akan mengkaji tentang M. Quraish Shihab sebagai penafsir terkemuka Indonesia yang senantiasa membumikan penafsiran Al-Qur'an ke dalam konteks Indonesia. Lebih jauh, artikel ini akan berfokus kepada upaya M. Quraish Shihab mentransmisikan penafsirannya yang semula dalam bentuk kitab Tafsir Al-Misbah menjadi "Kajian Tafsir Al-Misbah".

\section{Tradisi Penafsiran di Indonesia dan Posisi M. Quraish Shihab}

Dilihat dari segi sejarah penafsiran Al-Qur'an di Indonesia, sejarah umat Islam senantiasa diliputi oleh sejarah penafsiran Al-Qur'an, dari klasik hingga modern, seperti Tafsir Surah Al-Kahfi: 9 di masa pemerintahan Sultan Iskandar Muda (1607$1636 \mathrm{M}),{ }^{10}$ pada abad 17-19 M, di sana muncul Tarjuman al-Mustafid karya Abdul

\footnotetext{
${ }^{5}$ Ahmad Asy-Syirbashi, Sejarah Tafsir Qur'an, (Surakarta: Pustaka Firdaus, 1994), 15.

${ }^{6}$ Mohammad Ridho, Islam, Tafsir dan Dinamika Sosial, Ikhtiar Memaknai Ajaran Islam (Yogyakarta: Penerbit Teras, 2010), 4.

${ }^{7}$ Mahfudz Masduki, Tafsir al-Mishbah M. Quraish Shihab: Kajian atas Amtsal Al-Qur'an (Yogyakarta: Pustaka Pelajar, 2012), 13.

${ }^{8}$ Lihat Howard M. Federspiel, Kajian Al-Qur'an di Indonesia, terj. Tajul Arifin (Bandung: Penerbit Mizan, 1996), 298.

${ }^{9}$ M. Quraish Shihab, Wawasan Al-Qur'an: Tafsir Maudhui atas Pelbagai Persoalan Umat (Bandung: Penerbit Mizan, 1996), v.

${ }^{10}$ Islah Gusmian, Khazanah Tafsir Indonesia: dari Hermenutika hingga Ideologi, (Jakarta: TERAJU, 2003), 53-54.
} 
Rauf al-Sinkili, Tafsir Marah Labib (Tafsir al-Munir) karya Nawawi Bantani, ${ }^{11}$ pada era modern di antaranya Tafsir Al-Qur'an al-Karim karya Mahmud Yunus, Tafsir alAzhar karya Hamka, Tafsir Al-Qur'an al-Madjied dan Tafsir al-Bayan karya Hasbi ashShidieqy, dan lain sebagainya ${ }^{12}$ Adapun karya tafsir yang muncul pada era kontemporer di antaranya Tafsir al-Mishbah: Pesan, Kesan, dan Keserasian Al-Qur'an, karya M. Quraish Shihab, Al-Qur'an dan Tafsirnya, Tim UII Yogyakarta, Konsep Kufr dalam Al-Qur'an: Suaru Kajian Teologis dengan Pendekatan Tafsir Tematik, karya Harifuddin Cawidu, dan lain sebagainya. ${ }^{13}$

Dari berbagai karya yang lahir di setiap zaman tersebut di atas menunjukkan adanya perhatian tersendiri dalam perkembangan karya tafsir di Indonesia. Demkian halnya dengan saat ini yang terus bermunculan penafsir-penafsir Indonesia yang tidak hanya pada kitab tafsir, tetapi telah memasuki di ruang media sosial. Di antara penafsir di ruang medis sosial adalah Salman Harun dalam akun facebooknya sejak 2009 dan dalam website Salman Harun Institute, ${ }^{14}$ Nadirsyah Hosen juga dalam akun facebooknya yang kemudian dibukukan menjadi Tafsir Al-Qur'an di Medsos, ${ }^{15}$ dan lain sebagainya. Lebih dari itu, terdapat juga fenomena penafsiran Al-Qur'an yang semula dilakukan dalam bentuk tulisan kemudian diulas kembali dalam bentuk lisan, hal inilah yang sebagaimana dilakukan oleh Warith Deen Mohammed dan Syaikh Hamza Yusuf di Amerika, ${ }^{16}$ M. Quraish Shihab ${ }^{17}$, dan lain sebagainya. Penafsiran M. Quraish Shihab tersebut dilakukan dari kitab Tafsir Al-Misbah kemudian disampaikan kembali dalam "Kajian Tafsir Al-Misbah"18. Fakta ini menunjukkan bahwa penafsiran Al-Qur'an tidak hanya berhenti pada kawasan timur tengah (Arab) semata, sehingga pada akhirnya dapat disimpulkan bahwa tafsir tidak harus diidentik dengan Arab. Artinya tafsir produk 'lokal' juga memiliki makna signifikan dalam perkembangan penafsiran AlQur'an di Indonesia, bahkan di dunia.

M. Quraish Shihab sendiri tidaklah asing bagi pengkaji Al-Qur'an, terutama memasuki era modern-kontemporer. Ia merupakan seorang mufassir kontemporer di Indonesia. Berbagai peran penting telah dilaluinya, misalnya menjadi rektor IAIN

\footnotetext{
${ }^{11}$ Cucu Surahman, Pergeseran Pemikiran Tafsir di Indonesia: Sebuah Kajian Bibliografis", Afkaruna: Jurnal Ilmu-Ilmu Keislaman 10, no. 2, (2014): 217-232.

${ }^{12}$ Surahman, Pergeseran Pemikiran Tafsir di Indonesia, 217-232.

${ }^{13}$ Surahman, Pergeseran Pemikiran Tafsir di Indonesia, 217-232.

${ }^{14}$ Lihat Muhammad Wildan Imaduddin, "Facebook sebagai Media Baru Tafsir Al-Qur'an di Indonesia (Studi atas Penafsiran Al-Qur'an Salman Harun)", dalam jurnal Maghza 2, no 2 (2017): 69-80; Fadli Lukman, "Digital Hermenutics and a New Face of the Qur'an Commentary: the Qur'an in Indonesia's Facebook," dalam jurnal Al-Jami'yah 56, no. 1 (2018).

${ }^{15}$ Lihat Mutmainnaturrihza, "Dialektika Tafsir Media Sosial di Indonesia: Studi Penafsiran Nadirsyah Hosen di Media Sosial," dalam jurnal Hermeneutik 12, no. 01 (2018): 189-206; Sriwayuti, "Paradigma Penafsiran Al-Qur'an (Studi Buku Tafsir Al-Qur'an di Medsos Karya Nadirsyah Hosen)", Tesis, UIN Walisongo Semarang, 2019.

${ }^{16}$ Timur Raufovich Yuskaev, "The Qur'an Comes to America: Pedagogies of Muslim Collective Memory," Dissertation, University of North Carolina at Chapel Hill. 2010.

${ }^{17}$ Lihat Dessi Yanti Sri Budingsih, "Pandangan Muhammad Quraish Shihab tentang Hukum Hijab Muslimah", Tesis IAIN Walisongo Semarang, 2013.

${ }^{18}$ Lihat Ikhwan, Munirul, "An Indonesian Initiative to Make the Qur'an Down-to-Earth: Muhammad Quraish Shihab and His School of Exegesis”, Dissertation, Universität Berlin, Berlin. 2015.
} 
Syarif Hidayatullah Jakarta pada tahun 1992-1998, Ketua Majelis Ulama Indonesia (Pusat) pada tahun 1985-1998, anggota MPR-RI pada tahun 1982-1987 dan 1987-2002, sampai menjadi Mentri Agama Republik Indonesia pada tahun 1998. Nama direktur Pusat Studi Al-Qur'an ini bahkan tercantum sebagai salah satu tokoh ulama yang berpengaruh di dunia, yakni 500 muslim paling berpengaruh di dunia. ${ }^{19}$ Tidak hanya itu, karya-karyanya telah sangat banyak, baik dari segi tafsir Al-Qur'an, hukum Islam, sejarah, maupun lainnya, yang menjadikannya sebagai ulama yang sangat produktif.

M. Quraish Shihab lahir pada 16 Februari 1944, di Rappang, Kabupaten Sidenreng Rappang, Sulawesi Selatan, Ia termasuk keluarga yang mempunyai garis keturunan Arab Quraish, yakni Bugis yang terpelajar. Sejak kecil ia telah akrab dengan Al-Qur'an, ayahnya selalu mengikutkannya dalam pengajian Al-Qur'an yang diadakannya, selain menyuruhnya membaca Al-Qur'an. Bahkan sejak umur 6-7 tahun, ia telah sering didengarkan kisah-kisah dalam Al-Qur'an oleh ayahnya. Inilah yang menyebabkan ia sangat berminat untuk mengkaji dan mendalami Al-Qur'an. ${ }^{20}$ Sekolah dasar Quraish Shihab diselesaikan di Makassar, setelah itu ia melanjutkan studinya di Pondok Pesantren Dar al-Hadis al-Faqhiyah, Malang. Belum selesai di pesantren tersebut, pada tahun 1958 M, Quraish Shihab pindah ke sekolah Tsanawiyah al-Azhar, dan dilanjutkannya pada jenjang SMA di negeri Piramida itu. Pada tahun 1967, ia berhasil mendapat gelar Lc, yang kemudian disusul gelar M.A. pada tahun 1696 dengan jurusan yang sama. Selanjutnya, tahun 1982 M, Quraish Shihab akhirnya merai gelar Doktornya dalam bidang ilmu Al-Qur'an. ${ }^{21}$

Menurut Howard M. Federspiel bahwa perjalanan pendidikannya tersebut di atas menjadikan M. Quraish Shihab unik dan terdidik dengan baik. Hal ini disebabkan pada saat itu untuk pendidikan setingkat demikian, biasanya dicapai di Barat. ${ }^{22} \mathrm{M}$. Quraish Shihab dikenal sebagai cendekiawan, tokoh ulama, serta mufassir yang mampu menyelaraskan konteks masa kini dengan kandungan Al-Qur'an yang disampaikannya. ${ }^{23}$ Karena itu, tidak heran jika sangat banyak peneliti yang mengkaji tentangnya, di antaranya yang dilakukan oleh Munirul Ikhwan (2015) ${ }^{24}$, Muzayyin $(2015)^{25}$, Adilah Mahmud (2019) $)^{26}$, Amiruddin Siahaan (2016) ${ }^{27}$, Anwar Mujahidin dan

\footnotetext{
${ }^{19} \mathrm{Https} / / /$ id.wikipedia.org/wiki/Muhammad_Quraish_Shihab. diakses pada 28 September 2017. Lebih jauh lihat situs http://themuslim500.com. Diakses pada 28 September 2017.

${ }^{20}$ Muaddibi Asfiyak R, "Hermeneutika Al-Qur'an M. Quraish Shihab dalam Tafsir Al-Mishbah", Skripsi UIN Sunan Kalijaga Yogyakarta, 2017, 28.

${ }^{21}$ Muhammad Yusuf Sidik, "Penafsiran Ayat-ayat yang Dimaknai Hubungan Seksual Suami Istri menurut M. Quraish Shihab dalam Tafsir Al-Mishbah”, Skripsi UIN Sunan Kalijaga 2016, 25.

${ }^{22}$ Howard M. Federspiel, Kajian Al-Qur'an di Indonesia, terjemah Tajul Arifin (t.tp.: t.p, t.t), 294.

${ }^{23}$ Abd. Mufid, "Perbandingan Kerajaan Allah Menurut Stephen Tong dan Al-Mulk Menurut M. Quraish Shihab”, Skripsi UIN Sunan Kalijaga, 2012, 94.

${ }^{24}$ Ikhwan, Munirul, “An Indonesian Initiative to Make the Qur'an Down-to-Earth: Muhammad Quraish Shihab and His School of Exegesis", Dissertation, Universität Berlin, Berlin. 2015.

${ }^{25}$ Muzayyin, "Resepsi Hermeneutika dalam Penafsiran Al-Qur'an oleh M. Quraish Shihab: Upaya Negosiasi antara Hermeneutika dan Tafsir Al-Qur'an untuk Menemukan Titik Persamaan dan Perbedaan", dalam jurnal NUN1, no 1 (2015): 111-139.

${ }^{26}$ Adilah Mahmud, "Konsep At-Tijarah dalam Tafsir Al-Misbah Karya M. Quraish Shihab" dalam jurnal Al-Asas 2, no. 2 (2109): 87-108
} 
Zamzam Farrihatul Khoiriyah (2018) ${ }^{28}$ Mahfudz Masduku (2012) ${ }^{29}$, dan masing sangat banyak lagi yang tidak dapat diungkapkan di sini. Hal ini menunjukkan bahwa kiprah M. Quraish Shihab menjadi bagian penting dalam sejarah dan perjalanan tafsir AlQur'an di Indonesia.

\section{TAFSIR AL-MISBAH: tentang Karya Tulis dan Lisan}

Sebelumnya telah dibahas posisi M. Quraish Shihab dalam tradisi penafsiran Al-Qur'an di Indonesia, di sana dipahami bahwa M. Quraish Shihab senantiasa mendapat perhatian yang signifikan sebagai penafsir yang terkemuka, sehingga banyak sarjana yang mengkaji penafsir-penafsirannya. Dalam hal ini, penafsiran M. Quraish Shihab yang paling populer terdapat pada Tafsir Al-Misbahnya. Tafsir Al-Misbah adalah salah satu karya fenomenal M. Quraish Shihab yang akhirnya tidak hanya berbentuk kitab tetapi juga disampaikan dalam bentuk kajian. Hal ini memberi perspektif tersendiri bahwa penafsiran M. Quraish Shihab tidak berhenti pada tafsir tulis semata, tetapi juga dilakukannya dalam bentuk lisan. Namun, sebelum memasuki tafsir Al-Misbah M. Quraish Shihab dari tulis ke lisan, kiranya perlu dipaparakan terlebih dahulu tentang apa yang dimaksud tafsir tulis dan lisan di sini.

Tafsir tulis yang dimaksud di sini adalah upaya membuka makna dan kandungan Al-Qur'an yang dituangkan dalam bentuk tulisan. Penafsiran seperti ini telah banyak dilakukan baik di kalangan sahabat, maupun oleh ulama-ulama sepanjang sejarah, baik pada era klasik, pertengahan, maupun pada era modern-kontemporer. ${ }^{30}$ Berkenaan dengan ini, tidak jarang sahabat tidak hanya menulis Al-Qur'an, akan tetapi juga memberinya penjelasan tentang maksud dari ayat Al-Qur'an itu, sekalipun pada saat itu tradisi tulis masih tergolong langka. ${ }^{31}$ Sementara, penafsiran secara lisan dilakukan dengan menyampaikan makna dan kandungan Al-Qur'an dengan pengucapan langsung kepada audience (pendengar). Penafsiran secara lisan ini sebenarnya telah dilakukan oleh Nabi Muhammad sendiri, sebagaimana dapat dijumpai dalam hadishadis Nabi, ${ }^{32}$ hal ini dapat diketahui dari berbagai penjelasan yang dilakukan oleh Nabi

\footnotetext{
${ }^{27}$ Amiruddin Siahaan, "Profesionalitas Guru Menurut M. Quraish Shihab dalam Tafsir Al-Misbah", dalam jurnal Miqat 11, no. 2 (2016): 308-327.

${ }^{28}$ Anwar Mujahidin, Zamzam Farrihatul Khoiriyah, "Konsep Pendidikan Prenatal dalam Perspektif Tafsir Al-Misbah Karya M. Quraish Shihab", dalam jurnal Ta'allum: Jurnal Pendidikan Islam 6, no.1 (2018).

${ }^{29}$ Mahfudz Masduki, Tafsir al-Mishbah M. Quraish Shihab: Kajian atas Amtsal Al-Qur'an (Yogyakarta: Pustaka Pelajar, 2012).

${ }^{30}$ Misalnya penafsiran yang terdapat dalam mushaf 'Aisyah tentang QS. al-Baqarah: 238, sebagaimana yang ditemukan oleh budak perempuannya yang bernama Hamidah binti Yunus dalam

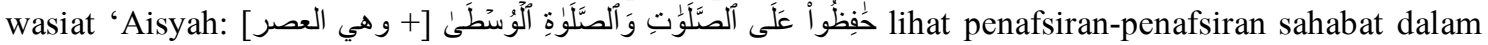
Ignaz Goldziher, Mazhab Tafsir dari Klasik hingga Modern, terjemah M. Alaika Salamullah, dkk (Yogyakarta: Penerbit eLSAQ Press, 2010), 25.

${ }^{31}$ M. Quraish Shihab, Membumikan Al-Qur'an: Memfungsikan Wahyu dalam Kehidupan (Tangerang: Lentera Hati, 2011), 570.

${ }^{32}$ Lihat Andreas Gorke, "Redefining the Borders of Tafsir: Oral Exegesis, Lay Exegesis and Regional Particularities", dalam Omar Ali-de-Unzaga, Tafsir and Islamic Intelectual History (London: Oxford University Press, 2014), 363.
} 
tentang kandungan Al-Qur'an yang tidak (atau sulit) dipahami oleh sahabat. ${ }^{33}$ Berdasarkan hal inilah yang menjadikan Nabi Muhammad sebagai mufassir pertama. Contoh penafsiran lisan yang dilakukan oleh Nabi, dapat dilihat ketika beliau membahas tentang QS. al-Baqarah: 187, yakni tali putih dari tali hitam, Nabi menjelaskannya sebagai cahaya siang/fajar dan kegelapan malam. Penjelasan Nabi seperti ini disebut ta'rif, yakni penegasan atas ayat Al-Qur'an. ${ }^{34}$

\section{Kitab Tafsir Al-Misbah (2002)}

Dapat dikatakan bahwa kitab Tafsir Al-Misbah merupakan karya kedua kitab tafsir yang ditulis oleh Quraish Shihab, setelah Tafsir Al-Qur'an Al-Karim, ${ }^{35}$ yang di dalamnya membahas 22 surah dan ditafsirkan secara tahlili. Namun, untuk menjadi sajian umum, tafsir Al-Qur'an Al-Karim tersebut kurang menarik, bahkan muncul kritikan bahwa penyajiannya terlalu bertele-tele. Sehingga menjadikan Quraish Shihab tidak puas dengan karyanya itu, sehingga ia kemudian menulis kitab tafsir yang berusaha menyajikan bahasan tiap surah dengan semula menjelaskan tujuan, atau tema pokok surah. ${ }^{36}$ Dengan berlandaskan pada (perlu) adanya penjelasan tema dan tujuan surah, Quraish Shihab mencoba membuka kandungan Al-Qur'an dengan "Pesan, Kesan, Keserasian" yang dapat dipahami bagi pembacanya. Hal ini sebagaimana yang tertera pada judul tafsirnya, yakni Tafsir al-Misbah: Pesan, Kesan dan Keserasian AlQur'an.

Adapun 'pesan' yang hendak disampaikan dalam kitab ini adalah bahwa ada pesan utama dalam tiap Al-Qur'an yang dapat ditemukan melalui mendalami dan memahami tema-tema pokok dari surah tersebut, yang apabila tema-tema sebanyak 114 surah dalam Al-Qur'an dapat dipahami, maka Al-Qur'an akan dengan mudah dipahami dan tentu menjadi dekat kepada pembacanya. ${ }^{37}$ 'Kesan' yang juga menjadi perhatian Quraish Shihab di sini adalah bahwa dengan memaparkan tema pokok dan tujuan dari setiap surah dapat menciptakan kesan yang benar sekaligus meluruskan kesan yang keliru dengan munculnya pengkhususan satu surah dibandingkan surah lainnya. Lebih jauh, Quraish Shihab mengkritik adanya fenomena pengistimewaan dan pengkhususan terhadap surah-surah tertentu, misalnya surah Yasin, al-Waqiah, alRahman. Hal ini -menurut Quraish Shihab- disebabkan kesalahpahaman atas maksud dari ayat-ayat yang dibacanya, terlebih lagi jika kesalahpahaman tersebut dilandasi oleh hadits-hadits yang lemah. ${ }^{38}$

\footnotetext{
${ }^{33}$ Imam Musbikin, “Mutiara” Al-Qur'an, khazanah Ilmu Tafsir dan Al-Qur'an (Madiun: Jaya Star Nine, 2014), 5-6.

${ }^{34}$ Lihat lebih jauh dalam M. Quraish Shihab, Kaidah Tafsir (Tangerang: Penerbit Lentera Hati, 2015), 358-359.

${ }^{35}$ M. Quraish Shihab, Tafsir Al-Qur'an Al-Karim, (Jakarta: Pustaka Hidayah, 1997).

${ }^{36}$ M. Quraish Shihab, Tafsir Al-Mishbah: Pesan, Kesan dan Keserasian Al-Qur'an, Vol. I, (Jakarta: Lentera Hati, 2002), ix.

${ }^{37}$ Shihab, Tafsir Al-Mishbah: Pesan, Kesan dan Keserasian Al-Qur'an, ix.

${ }^{38}$ Shihab, Tafsir Al-Mishbah: Pesan, Kesan dan Keserasian Al-Qur'an, ix-x.
} 
Adapun 'keserasian' dalam kitab tafsirnya ini bermakna bahwa sistematika penyusunan ayat dan surah dalam Al-Qur'an mempunyai keserasian yang di dalamnya mengandung unsur pendidikan yang sangat menyentuh. Lebih jauh, untuk menyerasikan ayat satu dengan ayat lain, seringkali dibutuhkan penyisipan-penyisipan kata atau kalimat yang berfungsi sebagai penjelasan (tafsiran), hal ini juga sebagai jembatan pemahaman terhadap gaya bahasa Al-Qur'an yang cenderung kepada 'ijaz (penyingkatan). ${ }^{39}$ Selanjutnya, Quraish Shihab melalui karyanya ini hendak menyampaikan bahwa Al-Qur'an tidak hanya sekedar dibaca, tetapi lebih dari itu. AlQur'an seharusnya diteliti dan didalami, sebagaimana makna yang termuat pada kata iqra' dalam wahyu pertama (QS. al-Alaq). Lebih jauh, bacaan yang dilakukan hendaknya diiringi dengan kesadaran atas keagungan Al-Qur'an, menghayatinya disertai dengan tazakkir dan tadabbur. Berkenaan dengan ini, bahkan Allah mengecam orang tidak memfungsikan akal dan hatinya dalam memahami Al-Qur'an (lihat QS. Muhammad: 20). ${ }^{40}$

Selanjutnya, dalam sebuah rekaman video di akun facebook 'Shihab dan Shihab', Quraish Shihab menyinggung tentang karya besarnya, yakni Tafsir al-Misbah. Ia mengatakan bahwa dalam menulis kitab tafsir al-Misbah tidak pernah sedikitpun terpikir untuk sampai ke lima belas jilid, bahkan rencana awalnya tidak lebih dari empat jilid. Tetapi ketika menyelami Al-Qur'an, semakin menyelaminya Quraish Shihab semakin terbuai oleh cahaya Al-Qur'an, sampai-sampai ia tidak sadar telah sampai lima belas jilid. Bahkan -menurut pengakuannya- ia masih merasa masih sangat banyak kandungan Al-Qur'an yang belum ia jelaskan, ini karena semakin orang mendekati Al-Qur'an maka semakin banyak kandungan yang akan ditemui bagi pengkaji al-Qur'a itu. ${ }^{41}$

Karya fenomenal dari Quraish Shihab ini terdiri atas lima belas (XV) jilid, yang berhasil membahas keseluruhan 30 juz Al-Qur'an atau 114 surah. Dari penjelasan yang termuat pada setiap jilid, maka tentu menghasilkan jumlah ketebalan berbeda dari satu jilid ke jilid lainnya. Lebih jauh, dalam penyajiannya, kitab tafsir ini menampilkan uraian berdasarkan tafsir mushafi, yakni mengikuti urutan surah dalam mushaf(dari alFatihah sampai Al-Nas). Beberapa penjelasan dilakukan sebagai pengantar sebelum menafsirkan sebuah surah, di antaranya sebagai berikut: ${ }^{42}$ Pertama, Memberikan keterangan tentang jumlah ayat pada surah, serta tempat turunnya surah tersebut (Makkiyah atau Madaniyah). Kedua, Memberikan penjelasan tentang nama surah. Misalnya, nama lainnya (jika ada), ataupun alasan atas penamaan surah tersebut. Ketiga, Memberikan penjelasan tentang tema umum yang dibahas dalam surah tersebut. Keempat, Memberikan penjelasan keserasian atau munasabah surah sebelumnya. Kelima, Memberikan keterangan nomor urut surah, serta penjelasan

\footnotetext{
${ }^{39}$ Shihab, Tafsir Al-Mishbah: Pesan, Kesan dan Keserasian Al-Qur'an, x.

${ }^{40}$ Shihab, Tafsir Al-Mishbah: Pesan, Kesan dan Keserasian Al-Qur'an, vi.

${ }^{41}$ Lihat video rekaman "Shihab dan Shihab" episode kedua, dipublikasikan oleh Roney 118 pada tanggal 29 Juni 2017.

${ }^{42}$ Mahfudz Masduki, Tafsir Al-Mishbah M. Quraish Shihab, 22-23.
} 
singkat mengenai nama-nama surah yang turun sebelum ataupun setelah surah tersebut. Keenam, Memberikan penjelasan tentang asbab al-nuzul (jika ada).

M. Quraish Shihab dalam tafsir ini juga mengelompokkan beberapa ayat pada suatu surah sehingga menjadi kelompok-kelompok kecil, ayat-ayat yang dikelompokkan tersebut dianggap memiliki hubungan yang erat. Lebih jauh, Quraish Shihab dalam menyimpulkan, senantiasa memberikan penjelasan penting mengenai sisi-sisi munasabah atau keserasian dari surah tersebut. Adapun dalam menutup penafsirannya, ungkapan wa Allahu A'lam selalu dipilih dalam mengakhiri penjelasan pada setiap surat. ${ }^{43}$ Adapun mengenai corak penafsiran M. Quraish Shihab dalam kitab Tafsir Al-Misbah, terdapat dua kesimpulan yang secara sepintas lalu terkesan berbeda. Satu sisi menurut Mahmud Masduki menyebutkan bahwa corak penafsiran Quraish Shihab menggunakan corak penafsiran bil al-ma'tsur dan juga bil al-Ra'yi, yakni penafsiran yang berlandaskan atas riwayat-riwayat -baik ayat dengan ayat, dengan hadits, dengan pendapat sahabat, ataupun dengan tabi'in- sembari menggunakan analisis pemikirannya dalam menafsirkan Al-Qur'an. Tetapi lebih jauh -tambah Masduki- jika yang dominan atau yang paling umumlah yang mejadi tolak ukur dalam menentukan corak penafsiran sebuah kitab, maka kitab tafsir al-Misbah tergolong kitab tafsir yang bercorak bil al-ma'tsur. ${ }^{44}$

Di sisi lain, Atik Wartini dengan berangkat dari teori objektifis tradisionalis, yang kemudian berkembang menjadi objektifis tradisionalis, objektifis revivalis, dan objektifis modernis, ${ }^{45}$ Atik menyimpulkan bahwa Quraish Shihab dalam penafsirannya menggunakan corak objektifis modern, yakni penafsiran Quraish Shihab yang membahas kosa kata, munasabah ayat, dan asbab al-nuzul ayat, serta menggunakan pendekatan sains dalam beberapa penafsirannya. Sekalipun dalam penafsirannya, Quraish Shihab selalu menggunakan riwayat kemudian ra'yu. ${ }^{46}$ Kedua kesimpulan tersebut di atas pada dasarnya tidaklah saling berbeda, apalagi bertentangan. Keduanya tetap menunjuk pada corak penafsiran Quraish Shihab yang cenderung mengkomparasikan riwayat dan ijtihad pemikirannya dalam membuka dan memahami kandungan Al-Qur'an. Lebih jauh, keduanya mengemukakan bahwa Quraish Shihab lebih mendahulukan sumber-sumber riwayat dari pada ijtihadnya. Karena itu, hemat penulis, bahwa corak penafsiran yang dilakukan Quriash Shihab adalah bil al-ma'tsur.

\footnotetext{
${ }^{43}$ Masduki, Tafsir Al-Mishbah M. Quraish Shihab, 23-24.

${ }^{44}$ Mahfudz Masduki, Tafsir Al-Mishbah M. Quraish Shihab, 36-37.

${ }^{45}$ Ciri obyektifis tradisionalis adalah menggunakan pendekatan bahasa semata. Obyektifis revivalis adalah menafsirkan Al-Qur'an dengan menggunakan pandangan ideologis dan biasanya menampakkan penafsiran yang eksrim (keras) terlebih lagi dalam persoalan jihad dan syari'at. Adapun obyektifis modern adalah menafsirkan Al-Qur'an dengan nuansa yang bermasyarakat dan sosial, selain itu juga memaparkan munasabah ayat, asbabun nuzul, dan lain sebagainya. Lihat lebih jauh Wartini, "Corak Penafsiran M. Quraish Shihab dalam Tafsir Al-Misbah", 121-123.

${ }^{46}$ Wartini, "Corak Penafsiran M. Quraish Shihab dalam Tafsir Al-Misbah”, 123.
} 


\section{“Kajian Tafsir al-Misbah"di MetroTV(2004)}

Kajian Tafsir al-Misbah merupakan lanjutan dari program acara Lentera Hati sejak tahun 2004. Secara umum kajian ini ditayangkan di MetroTV selama bulan ramadhan, tepatnya pada waktu sekitar pukul tiga WIB, waktu saat masih segarsegarnya pikiran untuk menimba ilmu. Tayangan kajian Al-Qur'an ini menjadi pembuka hari untuk umat Islam, terlebih lagi waktunya yang berada di waktu sahur dalam menyambut dan menjalani hari-hari ramadhan. Kajian yang berkisar 30 menit sampai 50 menit ini senantiasa dipandu oleh seorang (laki-laki atau perempuan) yang bertindak sebagai pembawa acara, yang bertugas menjadi pembuka kajian tersebut, menentukan arah kajian, mengadakan diskusi lanjut (tanya-jawab) antara Quraish Shihab dengan audience. Dalam kajian itu, kehadiran pembawa acara (host) bersifat dinamis (baca: berbeda-beda), kadang dalam satu tayangan host membuka acara dengan berhadapan langsung bersama penafsir (Quraish Shihab) dan audience. Kadang juga pembawa acara tidak dihadirkan langsung di ruang kajian, tetapi dibuka secara terpisah, hal ini tentu berdasarkan skenario penayangan.

Selain kehadiran host, kehadiran penonton juga tidak dapat dipastikan (dinamis) dari penayangan satu dengan lainnya. Bahkan seiring perkembangannya, kajian ini sesekali menghadirkan audience khusus, atau dikenal sebagai tamu dalam kajian tersebut. Tamu tersebut berasal dari berbagai kalangan, misalnya artis, musisi, bahkan sampai pejabat negara sekalipun, hal ini sebagaimana pernah dihadiri oleh Jusuf Kalla (wakil Presiden RI) pada tahun 2016. Selain diisi oleh ceramah atau penafsiran Quraish Shihab, pengadaan dialog atau sesi tanya jawab, dalam kajian ini juga menyajikan hiburan, baik sebagai pengantar acara maupun penjeda acara, yang dalam hal ini berbentuk nyanyian islami atau pemutaran film pendek islami, melalui berbagai hiburan tersebut menjadikan kajian tafsir al-Misbah tidak monoton. Melalui program ini, Quraish Shihab menafsirkan Al-Qur'an dengan menggunakan metode tahlili. Dalam penyajiannya, Quraish Shihab memaparkan kandungan Al-Qur'an berdasarkan susunan mushafi, yakni dari surah al-Fatihah sampai al-Nas. Siapapun yang menyaksikan tayangan ini akan dibawa oleh Quraish Shihab dengan durasi waktu sekitar satu jam untuk menyelusuri berbagai ragam penjelasan dan pemahaman yang terkandung dalam Al-Qur'an dengan bahasa yang mudah dipahami. ${ }^{47}$

Munir Ikhwan $^{48}$ mengatakan bahwa secara penyajian semua isi kajian seluruhnya dilakukan langsung oleh Quraish Shihab, dalam artian pihak pengelolah MetroTV tidak ikut andil dalam mengarahkan isi kajian tersebut. Adapun mengenai pengambilan gambar, objek rekaman, dan hal-hal yang berkaitan pertelevisian -lanjut

\footnotetext{
${ }^{47} \mathrm{Http} / /$ tvguide.co.id/program_acara_rutin/tafsir-al-mishbah-metro-tv. Diakses pada 24 Oktober 2017.

${ }^{48}$ Munirul Ikhwan adalah Dosen Pascasarjana UIN Sunan Kalijaga yang pernah menanyakan langsung tentang alasan Quraish Shihab hadir dalam media, termasuk dalam "Kajian Tafsir AlMishbah", hal ini berdasarkan penelitian disertasinya yang berjudul Munirul Ikhwan. "An Indonesian Initiative to Make the Qur'an Down-to-Earth: Muhammad Quraish Shihab and His School of Exegesis".
} 
Munir Ikhwan- tentu itu adalah tugas dari pengelolah siaran MetroTV. ${ }^{49}$ Kehadiran Quraish Shihab -sebagaimana diutarakan Munir Ikhwan- dalam dunia pertelevisian, termasuk program kajian tafsir al-Misbah, hendak menunjukkan bahwa ulama atau ilmuan perlu tampil di dunia media, hal ini agar umat Islam di Indonesia senantiasa 'memperhatikan' pandangan ulama-ulama berdasarkan kapasitasnya masing-masing. Jika tidak demikian, maka orang-orang 'lain' akan menyampaikan dan menyebarkan ajaran agama yang bukan menjadi bidangnya. ${ }^{50}$

\section{Contoh Membumikan Tafsir dalam Tafsir Al-Misbah}

Sebelumnya telah dibahas bahwa Tafsir Al-Misbah mengalami transmisi, dari tafsir tulis yang terdapat dalam kitab Tafsir Al-Misbah menjadi tafsir lisan di "Kajian Tafsir Al-Misbah”. Dalam penafsirannya, M. Quraish Shihab menafsirkan Al-Qur'an dengan mengalami perubahan atau perkembangan, dari yang dicantumkannya di dalam penafsiran tulisannya -dalam hal ini adalah kitab tafsir al-Misbah- dengan penafsiran yang dilakukannya dengan ceramah dalam kajian Tafsir al-Mishbah di Metro TV. Hal Ini dapat dilihat misalnya ketika Quraish Shihab menafsirkan makna sujud dalam QS. Al-Qalam: 43. Pada penafsiran tertulisnya, ia tidak banyak menjelaskan makna kata tersebut, melainkan hanya sujud -bagian dari gerakan dalam shalat. ${ }^{51}$ Akan tetapi, makna sujud yang disampaikan Quraish Shihab dalam bentuk lisan dibagi menjadi tiga, yakni (1) sujud bermakna yang menjadi bagian shalat, (2) sujud bermakna shalat karena sujud sebagai gerakan inti dari shalat, dan (3) sujud bermakna kepatuhan secara umum kepada Allah. ${ }^{52}$

Cotnoh lainnya, penafsiran M. Quraish Shihab kata shalihin yang terdapat dalam QS. Al-Qalam: 50, pada penafsiran tulis M. Quraish Shihab menafsirkan kata tersebut sebagai kelompok para Nabi terkemuka. ${ }^{53}$ Sedangkan pada penafsiran lisan, M. Quraish Shihab membagi kata shalihin menjadi dua, yakni shalih sebagai Nabi, dan shalih sebagai orang yang berbuat baik dan bermanfaat. Adapun penjelasan mengenai pembagian makna shalih sebagai orang yang berbuat baik dan bermanfaat lebih jauh dapat dilihat sebagai berikut: ${ }^{54}$

Allah pilih dia menjadi salah seorang Nabi dan memasukkan dia dalam kelompok orang-orang yang saleh nah saleh itu apa artinya? saleh itu punya dua arti saleh bisa berarti baik bisa juga berarti bermanfaat jadi orang yang saleh orang yang lebih banyak kebaikannya dari keburukannya atau orang yang selalu

\footnotetext{
${ }^{49}$ Wawancara dengan Munirul Ikhwan di Ruang dosen Pascasarjana UIN Sunan Kalijaga pada 30 Oktober 2017.

${ }^{50}$ Wawancara dengan Munirul Ikhwan di Ruangan dosen Pascasarjana UIN Sunan Kalijaga pada 30 Oktober 2017.

${ }^{51}$ Lihat Shihab, Tafsir Al-Mishbah: Pesan, Kesan, dan Keserasian al-Qur'an, 396.

${ }^{52}$ Video rekaman Quraish Shihab tentang penafsiran surah al-Qalam ayat 33-43, dalam "Kajian Tafsir al-Mishbah" Metro TV, pada 13 Oktober 2005. Menit 19:12-22:54.

${ }^{53}$ Shihab, Tafsir Al-Mishbah: Pesan, Kesan, dan Keserasian al-Qur'an, 402.

${ }^{54}$ Video rekaman Quraish Shihab tentang penafsiran surah al-Qalam 44-52, dalam "Kajian Tafsir Al-Mishbah" di Metro TV, pada 15 Oktober 2005. Menit 22:12-23:02.
} 
memberi manfaat kepada pihak lain kalau orang tidak punya kebaikan atau kurang kebaikannya tidak wajar dia disebut shaleh dan kebaikan itu hendaknya menyentuh semua makhluk Tuhan, baik terhadap sesama manusia baik terhadap lingkungan baik terhadap diri sendiri.

\section{Penutup}

Dari berbagai penjelasan di atas, dapat ditarik kesimpulan bahwa tradisi penafsiran Al-Qur'an di Indonesia senantiasa berkembang seiring perkembangan zaman, yang semula berada dalam bentuk tulis dalam kitab-kitab kemudian memasuki penafsiran di media sosial, baik tulis maupun lisan. Berbagai penafsir pun semakin menampakkan perannya di ruang publik, termasuk M. Quraish Shihab. Sebagai penafsir terkemuka di Indonesia, M. Quraish Shihab tidak hanya menjadi rujukan para penafsir-penafsir, sarjana, atau kaum elit lainnya, tetapi juga ikut andil dalam membumikan tafsir di ruang masyarakat umum melalui karyanya Tafsir Al-Misbah dalam bentuk kitab dan kajian. Kitab Tafsir Al-Misbah adalah karya Fenomenal M. Quraish Shihab dalam menyederhakan bahasa penyampaian penafsirannya, setelah sebelumnya dianggap bertele-tele pada kitab Tafsir Al-Qur'an Al-Karimnya. Sementara, "Kajian Tafsir Al-Misbah" lahir sebagai upaya menjaga pemahaman AlQur'an oleh ahlinya, sehingga masyarakat mendapat penerangan pemahaman AlQur'an oleh orang yang benar-benar berada dalam kapasitasnya sebagai penafsir AlQur'an. Di samping itu, penyajian penafsiran Al-Qur'an M. Quraish Shihab mengalami inovasi, perubahan dan perkembangan makna dari apa yang disampaikan dalam bentuk kitab Tafsir hingga disampaikan dalam bentuk lisan pada "Kajian Tafsir Al-Misbah" di MetroTV.

\section{DAFTAR PUSTAKA}

Al-Kawwaz, Muhammad Karim, Kalam Allah: al-Janib al-Syafahi min al-Zahirah AlQur'aniyyah, Bairut: Dar al-Saqi, 2002.

Asfiyak, Muaddibi R, “Hermeneutika Al-Qur'an M. Quraish Shihab dalam Tafsir AlMishbah”, Skripsi UIN Sunan Kalijaga Yogyakarta, 2017.

Asy-Syirbashi, Ahmad, Sejarah Tafsir Qur'an, Surakarta: Pustaka Firdaus, 1994.

Budingsih, Dessi Yanti Sri, "Pandangan Muhammad Quraish Shihab tentang Hukum Hijab Muslimah", Tesis IAIN Walisongo Semarang, 2013.

Federspiel, Howard M., Kajian Al-Qur'an di Indonesia, terj. Tajul Arifin, Bandung: Penerbit Mizan, 1996.

Goldziher, Ignaz, Mazhab Tafsir dari Klasik hingga Modern, terjemah M. Alaika Salamullah, dkk, Yogyakarta: Penerbit eLSAQ Press, 2010. 
Gorke, Andreas, "Redefining the Borders of Tafsir: Oral Exegesis, Lay Exegesis and Regional Particularities", dalam Omar Ali-de-Unzaga, Tafsir and Islamic Intelectual History, London: Oxford University Press, 2014.

Gusmian, Islah, Khazanah Tafsir Indonesia: dari Hermenutika hingga Ideologi, Jakarta: TERAJU, 2003.

Http://themuslim500.com. Diakses pada 24 Oktober 2017.

Http://tvguide.co.id/program_acara_rutin/tafsir-al-mishbah-metro-tv. Diakses pada 24 Oktober 2017.

Https://id.wikipedia.org/wiki/Muhammad_Quraish_Shihab. diakses pada 24 Oktober 2017.

Ikhwan, Munirul, "An Indonesian Initiative to Make the Qur'an Down-to-Earth: Muhammad Quraish Shihab and His School of Exegesis", Dissertation, Universität Berlin, Berlin. 2015.

Lukman, Fadli, "Digital Hermenutics and a New Face of the Qur'an Commentary: the Qur'an in Indonesia's Facebook," dalam jurnal Al-Jami'yah 56, no1 (2018).

Mahmud, Adilah, "Konsep At-Tijarah dalam Tafsir Al-Misbah Karya M. Quraish Shihab" dalam jurnal Al-Asas 2, no. 2 (2109).

Masduki, Mahfudz, Tafsir al-Mishbah M. Quraish Shihab: Kajian atas Amtsal AlQur'an, Yogyakarta: Pustaka Pelajar, 2012.

Mufid, Abd., "Perbandingan Kerajaan Allah Menurut Stephen Tong dan Al-Mulk Menurut M. Quraish Shihab", Skripsi UIN Sunan Kalijaga, 2012.

Imaduddin, Muhammad Wildan, "Facebook sebagai Media Baru Tafsir Al-Qur'an di Indonesia (Studi atas Penafsiran Al-Qur'an Salman Harun)", dalam jurnal Maghza 2, no. 2 (2017).

Mujahidin, Anwar, Zamzam Farrihatul Khoiriyah, "Konsep Pendidikan Prenatal dalam Perspektif Tafsir Al-Misbah Karya M. Quraish Shihab”, dalam jurnal Ta'allum: Jurnal Pendidikan Islam 6, no. 1 (2018).

Musbikin, Imam, “Mutiara” Al-Qur'an, khazanah Ilmu Tafsir dan Al-Qur'an, Madiun: Jaya Star Nine, 2014.

Mustaqim, Abdul, Pergeseran Epistemologi Tafsir, Yogyakarta: PT LKiS Printing Cemerlang, 2011.

Mutmainnaturrihza, "Dialektika Tafsir Media Sosial di Indonesia: Studi Penafsiran Nadirsyah Hosen di Media Sosial," dalam jurnal Hermeneutik 12, no. 01 (2018).

Muzayyin, "Resepsi Hermeneutika dalam Penafsiran Al-Qur'an oleh M. Quraish Shihab: Upaya Negosiasi antara Hermeneutika dan Tafsir Al-Qur'an untuk Menemukan Titik Persamaan dan Perbedaan", dalam jurnal NUN 1, no 1 (2015).

Ong, Walter J., Kelisanan dan Keaksaraan, terj. Rika Iffati, (Yogyakarta: Gading Publishing, 2013). 
Ridho, Mohammad, Islam, Tafsir dan Dinamika Sosial, Ikhtiar Memaknai Ajaran Islam, (Yogyakarta: Penerbit Teras, 2010).

Shihab, M. Quraish, Kaidah Tafsir, (Tangerang: Penerbit Lentera Hati, 2015). , M. Quraish, Membumikan Al-Qur'an: Memfungsikan Wahyu dalam Kehidupan, (Tangerang: Lentera Hati, 2011).

, M. Quraish, Tafsir Al-Mishbah: Pesan, Kesan dan Keserasian Al-Qur'an, Vol. I, (Jakarta: Lentera Hati, 2002), h. ix. , M. Quraish, Tafsir Al-Qur'an Al-Karim, (Jakarta: Pustaka Hidayah, 1997). , M. Quraish, Wawasan Al-Qur'an: Tafsir Maudhui atas Pelbagai Persoalan Umat, (Bandung: Penerbit Mizan, 1996).

Siahaan, Amiruddin, "Profesionalitas Guru Menurut M. Quraish Shihab dalam Tafsir Al-Misbah", dalam jurnal Miqat 11, no. 2 (2016).

Sidik, Muhammad Yusuf, "Penafsiran Ayat-ayat yang Dimaknai Hubungan Seksual Suami Istri menurut M. Quraish Shihab dalam Tafsir Al-Mishbah", Skripsi UIN Sunan Kalijaga 2016.

Sriwayuti, "Paradigma Penafsiran Al-Qur'an (Studi Buku Tafsir Al-Qur'an di Medsos Karya Nadirsyah Hosen)", Tesis, UIN Walisongo Semarang, 2019.

Surahman, Cucu, "Pergeseran Pemikiran Tafsir di Indonesia: Sebuah Kajian Bibliografis", Afkaruna: Jurnal Ilmu-Ilmu Keislaman 10, no. 2 (2014).

Suryadilaga, M. Alfatih dkk, Metodologi Ilmu Tafsir, (Yogyakarta: Penerbit Teras, 2010).

Video rekaman "Shihab dan Shihab" episode kedua, dipublikasikan oleh Roney 118 pada tanggal 29 Juni 2017.

Video rekaman Quraish Shihab tentang penafsiran surah al-Qalam 44-52, dalam "Kajian Tafsir Al-Mishbah" di Metro TV, pada 15 Oktober 2005. Menit 22:1223:02.

Wartini, Atik, "Corak Penafsiran M. Quraish Shihab dalam Tafsir Al-Misbah”, dalam Jurnal Studia Islamika 11, no. 1 (2014).

Wawancara dengan Munirul Ikhwan di Ruang dosen Pascasarjana UIN Sunan Kalijaga pada 30 Oktober 2017.

Yuskaev, Timur Raufovich, "The Qur'an Comes to America: Pedagogies of Muslim Collective Memory," Dissertation, University of North Carolina at Chapel Hill. 2010. 